\title{
Reviewing the Effects of Ocean Acidification on Sexual Reproduction and Early Life History Stages of Reef-Building Corals
}

\author{
Rebecca Albright \\ Division of Climate Change and Ocean Acidification, Australian Institute of Marine Science, PMB 3, Townsville MC, \\ Townsville, QLD 4810, Australia \\ Correspondence should be addressed to Rebecca Albright, r.albright@aims.gov.au
}

Received 15 May 2011; Revised 20 August 2011; Accepted 24 August 2011

Academic Editor: Horst Felbeck

Copyright ( $) 2011$ Rebecca Albright. This is an open access article distributed under the Creative Commons Attribution License, which permits unrestricted use, distribution, and reproduction in any medium, provided the original work is properly cited.

Ocean acidification $(\mathrm{OA})$ is a relatively young yet rapidly developing scientific field. Assessing the potential response(s) of marine organisms to projected near-future OA scenarios has been at the forefront of scientific research, with a focus on ecosystems (e.g., coral reefs) and processes (e.g., calcification) that are deemed particularly vulnerable. Recently, a heightened emphasis has been placed on evaluating early life history stages as these stages are generally perceived to be more sensitive to environmental change. The number of acidification-related studies focused on early life stages has risen dramatically over the last several years. While early life history stages of corals have been understudied compared to other marine invertebrate taxa (e.g., echinoderms, mollusks), numerous studies exist to contribute to our status of knowledge regarding the potential impacts of OA on coral recruitment dynamics. To synthesize this information, the present paper reviews the primary literature on the effects of acidification on sexual reproduction and early stages of corals, incorporating lessons learned from more thoroughly studied taxa to both assess our current understanding of the potential impacts of OA on coral recruitment and to inform and guide future research in this area.

\section{Introduction}

Coral reefs harbor one of the most diverse ecosystems on the planet in terms of species complexity [1] and are sources of vast economic wealth through a variety of ecosystem goods and services [2]. Despite the profound ecological and economic importance of these valuable marine ecosystems, global degradation of coral reefs has resulted in unprecedented loss over the past several decades [3-8]. Given the current trends in reef degradation, it is critical to understand processes that may allow these valuable marine ecosystems to persist. The recovery and persistence of a population, and of a species, requires that levels of recruitment keep pace with the loss of adult individuals [9, 10]. Successful coral recruitment, that is, the introduction and inclusion of a new individual to a population, is generally determined by three sequential life history stages: (1) larval availability (including gamete production and successful fertilization), (2) settlement ecology (related to larval and substrate condition), and
(3) postsettlement ecology (growth and survival of the newly settled individual) [11]. Larval settlement and subsequent survival (recruitment) are processes that can control marine population dynamics $[12,13]$. Environmental factors that disrupt these processes can result in compromised recruitment or recruitment failure and profoundly affect marine population dynamics [12-15].

Ocean acidification refers to the increase in acidity (decrease in $\mathrm{pH}$ ) of the ocean's waters resulting from oceanic uptake of atmospheric $\mathrm{CO}_{2}$. Present-day atmospheric carbon dioxide $\left(p \mathrm{CO}_{2}\right)$ levels are estimated to be $387 \mathrm{ppm}$ [16], $30 \%$ higher than the natural range over the last 650,000 years [17]. $p \mathrm{CO}_{2}$ levels are increasing at a rate of $0.5 \%$ per year [16], 200 times faster than any changes that occurred during the last eight glacial cycles [17] and 8-15 times faster than any changes in the past $60 \mathrm{Myr}$, including the PaleoEocene Thermal Maximum (PETM) [18]. $p \mathrm{CO}_{2}$ levels are projected to double present-day values (reaching $750 \mathrm{ppm}$ ) by the end of this century (year 2100) [16]. Nearly 50\% 
of all $\mathrm{CO}_{2}$ emitted into the atmosphere over the last two and a half centuries has been absorbed by the oceans [19]. Consequently, seawater carbonate concentrations have been depleted by $\sim 30 \mu \mathrm{mol} \mathrm{kg}^{-1}$, simultaneously reducing the $\mathrm{pH}$ of the ocean's surface waters by 0.1 units relative to the preindustrial era (a 30\% increase in acidity) [16]. Further reductions of $0.3-0.5 \mathrm{pH}$ units are projected to occur by the end of this century as the oceans continue to absorb anthropogenic $\mathrm{CO}_{2}$ [16].

Documenting and predicting the response(s) of coral reefs and other marine ecosystems to changing ocean chemistry has been of recent concern in the scientific community. The number of ocean acidification-related studies has risen dramatically over the past several years leading to valuable insight regarding the future state of our oceans. While many acidification studies originally focused on the sensitivity of adult growth and calcification, mounting experimental evidence now suggests that numerous biological processes and physiological functions independent of calcification may be negatively impacted including sperm motility in urchins [20], corals and sea cucumbers [21], fertilization success in sea urchins $[20,22,23]$ but see $[24]$, molluscs $[25,26]$ but see [27] and corals [28], larval development and/or growth in crustaceans [29-32], molluscs [25, 33, 34], corals [28, 35-39] and echinoderms [22, 40-43], physiology and behavior of molluscs [34], survival of echinoderms [40, 41] and crustaceans [30], stress response in sea urchins [44, 45], and gene expression in sea urchins $[43,45]$. Early life history stages are thought to be particularly vulnerable [46], and recently documented declines in the growth of Caribbean coral recruits has given rise to the speculation that climate change and ocean acidification may already be interfering with recruitment dynamics [47].

The study of ocean acidification and its effects on early life history stages of corals is relatively new. Nonetheless, several published studies are available investigating the effects of elevated $p \mathrm{CO}_{2}$ on early developmental stages, including sexual reproduction, larval settlement, metabolism, algal symbiosis, survival, and postsettlement growth and calcification (Table 1). The present paper synthesizes and reviews these studies to formulate a basic understanding of how coral recruitment may respond to ocean acidification. For areas that are deficient in studies and for which a robust assessment is not possible, lessons learned from studies conducted on more thoroughly studied taxa (e.g., mollusks, echinoderms) are used to supplement the coral literature and to provide guidelines for future experiments.

\section{Sexual Reproduction}

Very little information is available regarding the effects of ocean acidification on sexual reproduction in corals. Evaluating effects of acidification on gamete development is difficult as gametogenesis can extend over 9-11 months for some species $[48,49]$, and maintaining colonies under experimental conditions for this period of time can prove challenging. Nonetheless, available studies indicate that gamete production may show resistance to acidification, although this question deserves further attention. Montipora capitata colonies grown under acidified conditions $\left(+365 \mu\right.$ atm $\left.p \mathrm{CO}_{2}\right)$ for 6 months did not show a decrease in gamete production compared to controls [50]. Similarly, normal gametogenesis was observed in Oculina patagonica and Madracis pharensis following 12 months exposure to acidified conditions $(\mathrm{pH}$ $7.3,7.6,8.0,8.3)$ [51]. While gametogenesis may proceed normally, a recent study found that spawning female corals are significantly more susceptible to the negative effects of ocean acidification than spawning male corals [52], leading the authors to conclude that the energetically costly process of egg production leaves little energy available to the coral to sustain "normal" calcification rates in the face of ocean acidification [53].

Fertilization studies indicate that elevated $p \mathrm{CO}_{2}$ negatively affects fertilization success of at least two species of coral, Acropora palmata [28] and Montastraea faveolata [54], but in these studies the effect of $p \mathrm{CO}_{2}$ was dependent on the sperm concentration (discussed further below). Acidification has been shown to have varying effects on the fertilization rate of other marine invertebrates. Elevated $p \mathrm{CO}_{2}$ negatively affects fertilization success in the oyster Saccostrea glomerata $[25,26]$, and the urchins, Echinometra mathaei, Hemicentrotus pulcherrimus ([22], although significant effects were only observed when acidification was severe: 5,000-10,000 ppm) and Strongylocentrotus franciscanus [23]. However, fertilization is unaffected by elevated $p \mathrm{CO}_{2}$ in the oyster Crassostrea gigas [27]. Interestingly, multiple studies on a single urchin species, Heliocidaris erythrogramma, yield inconsistent results-Havenhand et al. [20] showed that fertilization is negatively affected by $p \mathrm{CO}_{2}$ while Byrne et al. $[24,55]$ did not observe an effect.

2.1. Experimental Design. While differences in results among studies may be partially attributable to species-specific sensitivities, it is likely that methodological differences play a role. Multiple factors can interact to influence fertilization success in broadcast-spawning organisms, including, but not limited to, sperm-egg contact time, gamete compatibility (i.e., polyandry versus single male-female crosses), gamete aging, sperm velocity and motility, egg size, and sperm concentration (reviewed in [23,56]). While most studies do not provide sufficient detail in the methods to evaluate the role that some of these variables play in determining experimental results, details regarding sperm concentrations are consistently reported, and the interaction between treatment effect and sperm concentration deserves further consideration here.

For two studies conducted on corals, the magnitude of the $p \mathrm{CO}_{2}$ effect was dependent on the sperm concentration. For A. palmata, elevated $p \mathrm{CO}_{2}$ had little to no effect on fertilization at sperm concentrations that have previously been identified as "optimal", that is, achieving high fertilization success in laboratory experiments (approximately $10^{6}$ sperm $\mathrm{mL}^{-1}$ ); however, as sperm concentration declined, the effect of $p \mathrm{CO}_{2}$ was exacerbated [28]. Similar results were obtained for Montastraea faveolata [54]. Results of both experiments indicate that acidification does not alter the maximum achievable percent fertilization but rather affects fertilization 


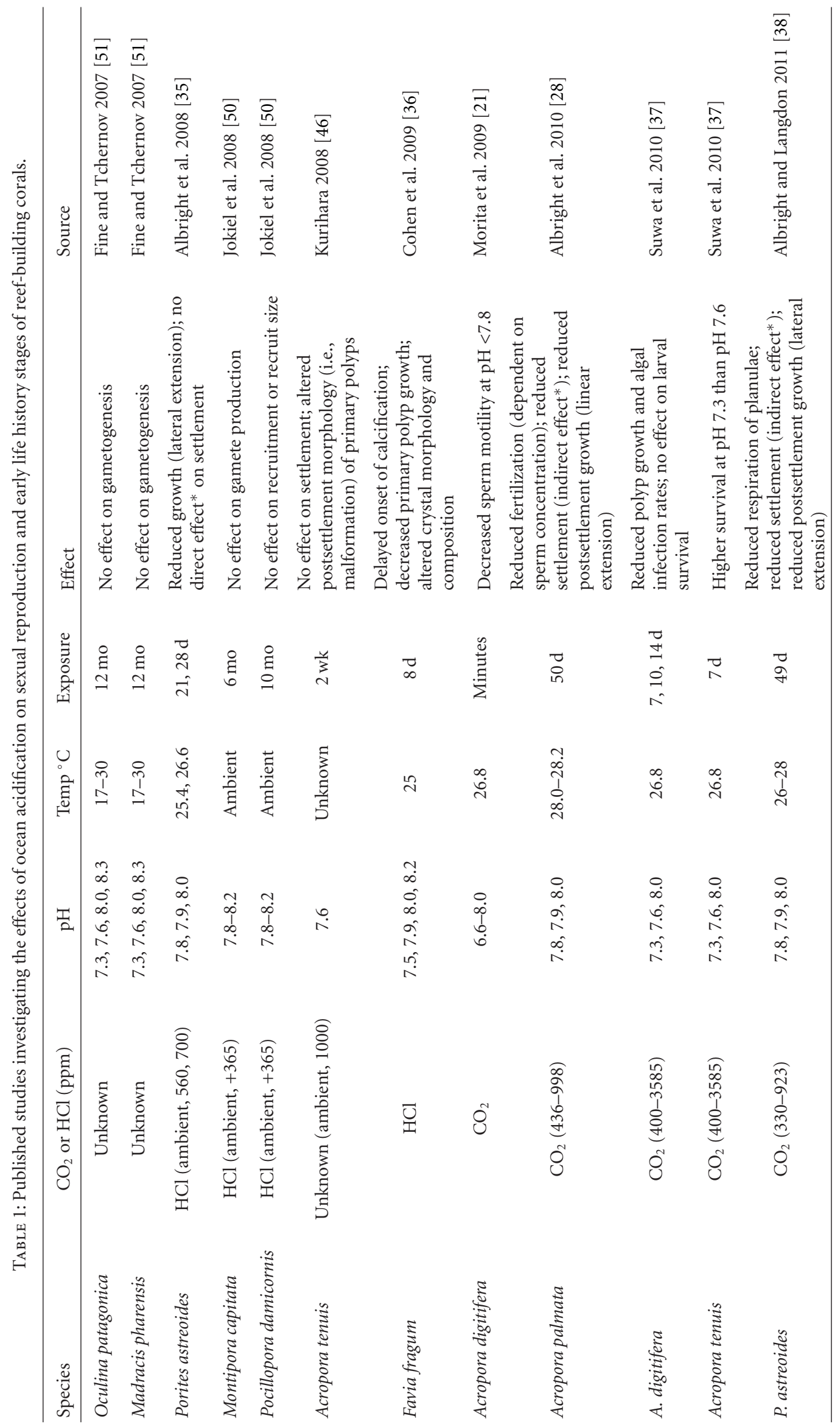




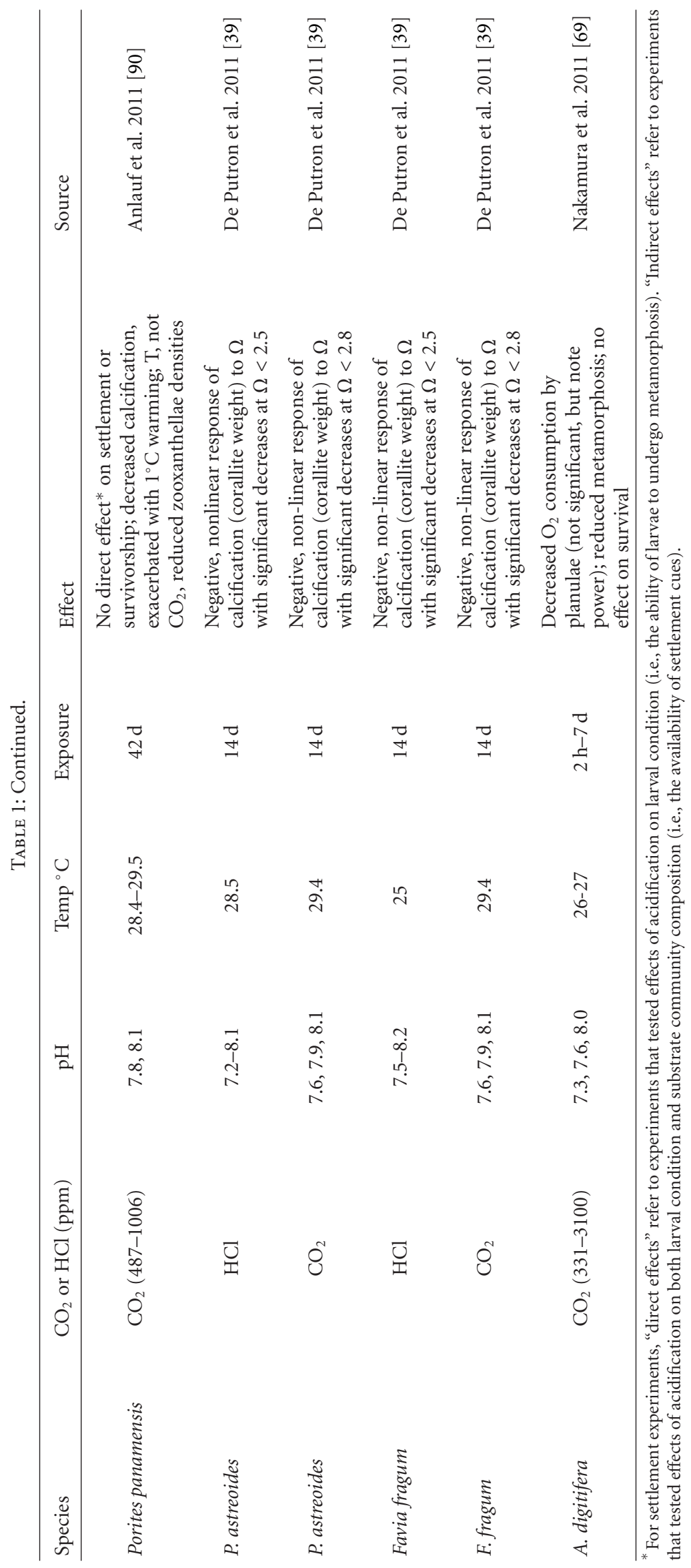


efficiency. In both studies, elevated $p \mathrm{CO}_{2}$ increased sperm limitation such that higher sperm concentrations were required to achieve comparable fertilization rates to controls.

Sperm concentration-specific effects of $p \mathrm{CO}_{2}$ on fertilization success have also been documented for a sea urchin, Strongylocentrotus franciscanus [23]. Similar to M. faveolata, $p \mathrm{CO}_{2}$ decreased fertilization efficiency (i.e., increased sperm limitation); elevated $p \mathrm{CO}_{2}$ also reduced the ability of urchin eggs to successfully block fertilization by multiple spermatozoa, that is, polyspermy, which inhibits embryo development [23]. Interactions between sperm concentration and treatment effect have also been acknowledged in ecotoxicology studies, where copper toxicity increased with decreasing sperm concentration in both sea urchins [57] and intertidal polychaete worms [56]. Recently, Byrne et al. [24] reported no effect of $p \mathrm{CO}_{2}$ on fertilization success of a sea urchin, Heliocidaris erythrogramma, across a range of sperm concentrations, indicating that fertilization in some species may be resistant to acidified seawater.

These studies underscore the need for caution when designing and interpreting experiments testing the effects of $\mathrm{CO}_{2}$ (and other environmental pollutants) on the fertilization of corals and other broadcast-spawning marine invertebrates. Since the probability of detecting a treatment effect may depend on the sperm concentration and how the fertilization curve changes under elevated $p \mathrm{CO}_{2}$ [23], to accurately assess the effect of elevated $p \mathrm{CO}_{2}$ on fertilization kinetics, it is critical to use a broad range of sperm concentrations which encompasses concentrations that are ecologically relevant for the study species. Employing multiple sperm concentrations also lends insight to the mechanism(s) responsible for observed reductions in fertilization $[23,56]$, information that is not discernable from a single concentration.

Unfortunately, many recent studies employ a single sperm concentration $[20,22,25,26,55]$, severely limiting our ability to make useful predictions about the likely impact of acidification on sexual reproduction. In many cases, the chosen sperm concentration has previously been identified as "optimal", that is, producing maximum fertilization success in the laboratory. However, the ecological relevance of "optimal" sperm concentrations is not well understood, as fertilization conditions in nature are poorly documented and likely highly variable. The few studies that have quantified in situ sperm concentrations for corals indicate that while "optimal" concentrations can be observed under certain circumstances, sperm concentration and fertilization rates are highly variable in both space and time [58]. For example, Omori et al. [59] reported sperm concentrations of $10^{6}$ sperm $\mathrm{mL}^{-1}$ one hour after spawning on a reef flat with $\sim 30 \%$ coral cover during calm weather conditions. However, concentrations rapidly declined and were approximately 0 within $6 \mathrm{~h}$ of spawning. Because sperm concentration depends on population density, time after spawning, wind and water turbulence, amongst other factors, identifying a single concentration that is both suitable for laboratory experiments and ecologically relevant is complex. Additional concerns regarding the use of a single sperm concentration in fertilization studies (e.g., inability to detect treatment effects due to underlying levels of polyspermy) are discussed in Hollows et al. [56] and Marshall [60].

\subsection{Mechanism behind Acidification-Induced Reductions in} Fertilization Success. Acidification-induced changes to the fertilization curve may be due to physiological effects on the sperm, egg, or both. For many marine invertebrates, including corals, sperm flagellar motility is likely initiated when intracellular $\mathrm{pH}([\mathrm{pH}] \mathrm{i})$ is elevated and suppressed when $[\mathrm{pH}] \mathrm{i}$ decreases (absolute values for $[\mathrm{pH}] \mathrm{i}$ are not available) [61]. A recent study showed that flagellar motility of Acropora digitifera sperm was significantly reduced when seawater $\mathrm{pH}$ decreased by 0.3 units ( 8.0 to 7.7 ). The authors conclude that an increase in $[\mathrm{H}+]$ outside of the cell interferes with $[\mathrm{pH}] \mathrm{i}$, inhibiting sperm motility and compromising the ability of sperm to move towards unfertilized eggs [21]. Similar results were obtained for a sea cucumber, Holothuria spp. [21]. Havenhand et al. [20] found that reducing the $\mathrm{pH}$ of seawater by $0.4 \mathrm{pH}$ units significantly reduced swimming speeds and percent motility of sea urchin sperm, Heliocidaris erythrogramma. These results are consistent with a previous study demonstrating that reduced seawater $\mathrm{pH}$ affects $[\mathrm{pH}] \mathrm{i}$ in sea urchin sperm, inhibiting mitochondrial respiration and motility [62]. Conversely, elevated $p \mathrm{CO}_{2}$ does not affect sperm motility in the oyster Crassostrea gigas [27], demonstrating that sperm of some species/taxa may be resistant to seawater acidification.

The fertilization potential of eggs may also be influenced by changes to $[\mathrm{pH}] \mathrm{i}$ and/or increased susceptibility to polyspermy [23]. While the fertilization process in corals is poorly understood, egg-derived sperm attractants have been described in at least one coral species, Montipora digitata [63], and a recent study observed that sperm motility increases in the vicinity of eggs prior to fertilization and decreases following fertilization [61]. Morita et al. [61] hypothesize that coral eggs secrete motility-inducing substances that increase sperm $[\mathrm{pH}] \mathrm{i}$ prior to fertilization and motility-suppressing substances immediately following fertilization to prevent polyspermy. Unlike many marine invertebrates, fertilization membranes to prevent polyspermy have not been described in coral eggs [61, 64]. While the effect of acidification on susceptibility to polyspermy has not yet been evaluated in corals, acidification-induced susceptibility to polyspermy has long been documented in other marine invertebrate taxa, though effects are typically only observed when acidification is severe. As early as 1924, researchers noted that sea urchin eggs (Arbacia spp.) fertilized in acidic conditions ( $\mathrm{pH}$ 7.2) showed higher rates of polyspermy compared to $\mathrm{pH}$ 7.4-9.8 [65]. In 1932, Tyler and Schultz demonstrated that fertilization in the marine worm Urechis caupo is more susceptible to decreased $\mathrm{pH}$ than later stages of development: exposure to acidified seawater, $\mathrm{pH}$ 7.2, prevents fertilization; however, if embryos are placed in acidic conditions immediately following fertilization, they undergo normal cleavage and development at $\mathrm{pH}$ values as low as 6.4 [66]. These results led to the hypothesis that acidification interferes with the initial stages of the fertilization reaction, namely, the block to polyspermy [66]. Smith and Clowes [65] concluded that this effect may be due 
to $\mathrm{CO}_{2} / \mathrm{H}^{+}$interference with the formation of a fertilization membrane. Recently, Reuter et al. [23] observed increased susceptibility to polyspermy in sea urchin eggs exposed to 1800 ppm $p \mathrm{CO}_{2}$, but no significant differences were observed at $800 \mathrm{ppm}$. In sea urchin eggs, $[\mathrm{pH}] \mathrm{i}$ increases immediately following insemination [67], triggering the initiation of embryonic development [68]; it is also possible that acidification interferes with $[\mathrm{pH}] \mathrm{i}$, inhibiting development. Because coral eggs may not have a fertilization membrane, the existence of a $p \mathrm{CO}_{2}$ effect on fertilization potential and the mechanism behind such an effect may differ from other marine invertebrate taxa; nonetheless, the potential for acidification to decrease fertilization potential of coral eggs and/or embryo viability is an area of research that has yet to be investigated and deserves consideration.

\section{Metabolism}

Significant reductions in metabolism have been reported for larvae of at least one brooding coral species, Porites astreoides, following exposure to acidified conditions [38]. During a $2 \mathrm{~h}$ exposure, larval metabolism decreased by $27-$ $63 \%$ at $\mathrm{pCO}_{2}$ levels that are projected to occur by the middle $(560 \mu \mathrm{atm})$ and end $(800 \mu \mathrm{atm})$ of this century. Using Acropora digitifera planulae, Nakamura et al. [69] observed a trend of decreasing oxygen consumption with increasing $p \mathrm{CO}_{2}$ following both 3 and 7 days of exposure; however these results were not significant. The authors acknowledge the low statistical power $(0.30)$ of their experiment, and results are, therefore, inconclusive [69]. Further studies are needed concerning the effects of elevated $p \mathrm{CO}_{2}$ on larval respiration. Comparisons of brooding (containing zooxanthellae) and spawning (devoid of zooxanthellae) larvae will shed light on whether certain reproductive strategies are more or less susceptible to acidified conditions during the planktonic stage.

Metabolic suppression resulting from exposure to acidified conditions has previously been reported to occur in a variety of adult marine invertebrates, including crabs [70], squid [71], worms [72], bivalves ([73], adult and juveniles), pteropods and amphipods (reviewed in [74]). Culturing sea urchin larvae in acidified conditions resulted in the downregulation of several genes involved in aerobic metabolism [43, 45]. Acidification reduces the heart rate of juvenile snails ([34], Littorina obtusata). Interestingly, acidification increases metabolism in juvenile oysters (Crassostrea virginica, [75]).

Metabolic suppression is considered an adaptive strategy for the survival of short-term hypercapnia and hypoxia (reviewed in [74]); however, slowed metabolism is generally achieved by halting energy-expensive processes, such as protein synthesis $[76,77]$, and therefore, if sustained, may lead to reductions in growth and reproductive potential [74]. Thus, metabolic suppression is not considered to be advantageous under chronic elevations of $\mathrm{CO}_{2}$, such as ocean acidification $[77,78]$.

Depressed metabolic rates in invertebrate larvae may hold implications for larval fitness and motility, thereby limiting dispersal and settlement rates. Recent work demonstrated that oxygen consumption and energy use in coral larvae (Acropora intermedia) peaks $\sim 5$ days after spawning, when larvae begin actively swimming and exploring [79]. During the planktonic dispersal phase, larvae of many species actively explore and change their position in the water column to locate ideal settlement sites $[80,81]$ and possibly influence horizontal transport and dispersal [82]. If metabolic suppression during the planktonic stage translates into decreased larval motility, the ability of larvae to regulate their vertical position in the water column may be compromised, thereby impacting dispersal and settlement potential.

\section{Settlement and Metamorphosis}

Larvae of many coral species actively select a site of permanent attachment using external chemical cues that induce metamorphosis [83-86]. Both positive settlement cues from crustose coralline algae (CCA) and/or microbial biofilms and settlement interference by turf algae have been previously documented [83, 87-89]. Environmental factors that alter or interfere with these cues have the potential to greatly impact coral recruitment and future population dynamics. Given that larval settlement can be influenced by conditions experienced in the plankton and by positive or negative cues on the benthos or in the overlying water column [11], to accurately assess whether acidification interferes with settlement, we must assess effects on larval condition, substrate condition, and the interaction between the two.

At least three studies have demonstrated that if settlement cues are present, acidified seawater does not directly impair the physiological ability of coral larvae to undergo metamorphosis and attach to the substrate $[35,38,90]$. Contrary to these findings, Nakamura et al. [69] observed a significant reduction in settlement of Acropora digitifera larvae following just $2 \mathrm{~h}$ exposure to acidified seawater. It is important to note that settlement substrates were not used in this experiment, and settlement was induced by the use of the coral metamorphosis-inducer peptide Hym-248, rather than using natural settlement inducers (e.g., CCA). Thus, the ecological significance of the results is not known. Kurihara [46] reported no effect of acidification (1000 $\mu \mathrm{atm}$ $p \mathrm{CO}_{2}$ ) on settlement by Acropora tenuis. However, methods were not provided for this experiment, and it is, therefore, difficult to assess the implications of these results. For other marine invertebrates, acidification has been shown to directly delay metamorphosis in at least 3 species of marine bivalves, including Crassostrea virginica, Argopecten irradians, and Mercenaria mercenaria [91, 92].

Studies that have evaluated the effect of acidification on both larval condition and substrate condition indicate that acidification has the capacity to influence larval settlement, but may primarily do so indirectly, by altering the substrate community composition and the availability of biological and chemical settlement cues [28, 38]. Albright and Langdon [38] showed that elevated $\mathrm{CO}_{2}$ causes changes in the epilithic algal community of settlement substrates; as $\mathrm{pH}$ declined, taxa known to facilitate larval settlement of some coral species (e.g., CCA) were replaced by alternate algal species (e.g., consortia dominated by diatoms and 
other chromophytes), resulting in reduced settlement of Porites astreoides larvae. These shifts in benthic community composition are consistent with previously published work demonstrating that CCA recruitment and growth decreases with decreasing $\mathrm{pH}[50,93,94]$. CCA precipitates highmagnesium calcite $13-15 \% \mathrm{MgCO}_{3}$ [95], a mineral phase of calcium carbonate that is $1.2-5$ times as soluble as aragonite $[96,97]$, rendering it particularly vulnerable to acidified conditions. The potential for acidification to indirectly affect settlement success by interfering with the availability of settlement cues is an important area of research that deserves further investigation.

While CCA and/or associated biofilms induce metamorphosis of some coral species, presence of CCA is not an obligate trait for settlement by all species. For example, while Acropora palifera larvae only metamorphose in the presence of coralline red algae [98], and Goniastrea retiformis preferentially settle onto substrates covered with CCA [99], Stylophora pistillata larvae are able to metamorphose in unfiltered seawater and onto glass coverslips [98], and Stylaraea punctata larvae prefer biofilmed rubble to CCA [99]. If acidification primarily affects settlement by altering the substrate community composition and the availability of settlement cues, then species that have more stringent settlement requirements (i.e., surface contact with CCA and/or associated biofilms) may be preempted by species that are capable of settling without these cues. In a 10-month experiment, Jokiel et al. [50] found that despite drastic reductions $(86 \%)$ in percent cover of CCA (acidified to $365 \mu$ atm above control values), Pocillopora damicornis larvae were still able to recruit at levels comparable to controls. Additionally, not all species of CCA induce larval settlement. Harrington et al. [100] showed that Acropora tenuis and A. millepora larvae settled at different rates in response to different species of coralline algae. Similarly, Ritson-Williams et al. [101] showed that A. palmata and A. cervicornis larvae demonstrate different behavioral responses to different CCA species. Evaluating species-specific sensitivities of CCA to acidification will facilitate a better understanding of potential shifts in benthic community composition and the implications for coral settlement and recruitment.

\section{Postsettlement Growth and Calcification}

The majority of available studies evaluating the effects of ocean acidification on early life history stages of corals assess postmetamorphic growth and calcification. General consensus from these studies is that primary polyp growth is hindered by increasing $p \mathrm{CO}_{2}$ and decreasing saturation state (Figure 1), with at least 7 species of coral exhibiting acidification-induced reductions in post-metamorphic calcification and/or growth: Porites astreoides [35, 38, 39], $P$. panamensis [90], A. digitifera, A. tenuis [37], A. palmata [28], Agaricia agaricites [54], and Favia fragum [36, 39, 54]. Acidification may also delay the onset of calcification and alter crystal morphology and composition [36]. These findings are consistent with the hypothesis that calcification depends strongly on saturation state, as has been documented for

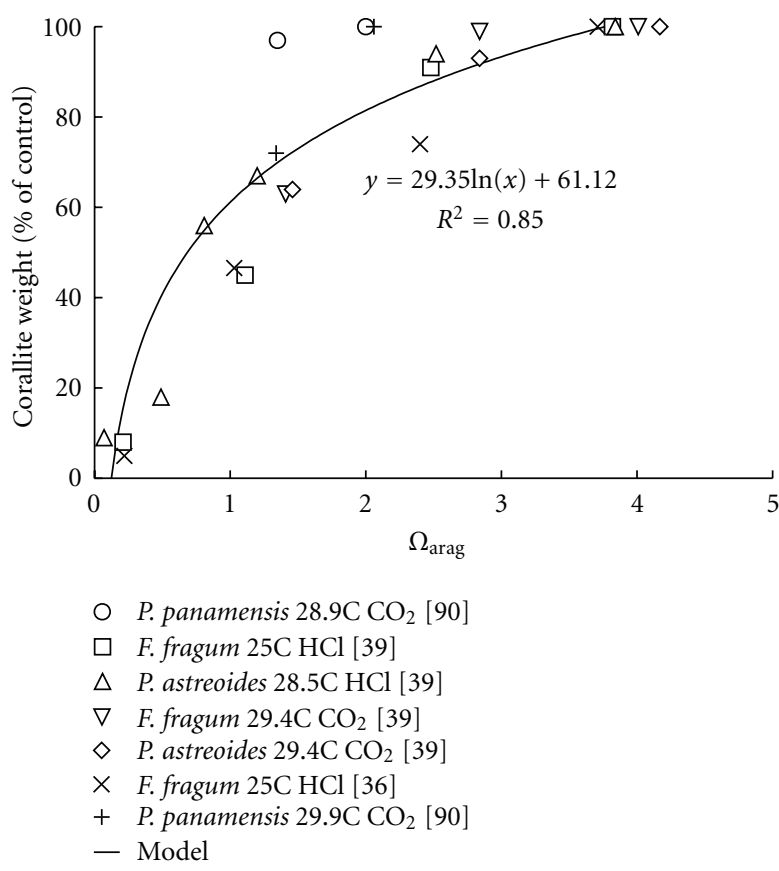

FIGURE 1: Effect of $\Omega_{\text {arag }}$ on postsettlement calcification rate expressed as a percentage of the control value. Data are from published studies on juvenile corals.

adults of several coral species and reef communities [102, 103].

Albright et al. [35] reared Porites astreoides recruits for 1 month in seawater manipulated with acid-addition and observed drastic declines in post-metamorphic growth with decreasing $\Omega_{\text {arag }}$. Skeletal growth, as measured by the increase in cross-sectional area, was reduced by $45-$ $84 \%$ as $\mathrm{CO}_{2}$ increased and $\Omega_{\text {arag }}$ decreased. The study was repeated using an improved experimental system $\left(\mathrm{CO}_{2}\right.$ bubbling and natural lighting); again, growth was positively correlated with saturation state (negatively correlated with $\mathrm{CO}_{2}$ ), although reductions in growth were less severe, 16$35 \%$ [38].

Cohen et al. [36] reared primary polyps of Favia fragum in seawater manipulated with acid-addition for 8 days and found a reduction in the size and weight of the primary corallite with decreasing $\Omega_{\mathrm{arag}}$. Interestingly, recruits were capable of calcifying in strongly undersaturated solutions $\left(\Omega_{\mathrm{arag}}=0.22\right)$, suggesting that, for some species, biological control may partially abate thermodynamically unfavorable conditions. Despite the ability to calcify in under saturated seawater, several negative effects were observed: the onset and rate of calcification were significantly delayed; crystal morphology was altered as the crystal aspect ratio (i.e., ratio of crystal length to crystal width) decreased with decreasing saturation state [53]; crystal organization became increasingly random (i.e., less densely packed); and shifts in mineralogy occurred as $\mathrm{Sr} / \mathrm{Ca}$ ratios increased and $\mathrm{Mg} / \mathrm{Ca}$ ratios decreased. Acidification-induced shifts in crystal morphology and organization were also reported for P. astreoides recruits [54]; similar effects were observed when seawater 
chemistry was manipulated with $\mathrm{HCl}$ and $\mathrm{CO}_{2}$ gas. Altered skeletal structure of new recruits may render them more susceptible to mechanical damage, reducing their ability to grow rapidly enough to ensure survival [36].

De Putron et al. [39] observed a nonlinear effect of $\Omega_{\text {arag }}$ on early calcification (corallite weight) of both $P$. astreoides and $F$. fragum: calcification was unaffected at saturation states greater than $\Omega_{\text {arag }}$ 2.5-2.8; however, drastic reductions in calcification were observed in both species when $\Omega_{\text {arag }}$ dropped below this threshold. The same effect was observed when seawater was acidified with $\mathrm{HCl}$ and $\mathrm{CO}_{2}$ gas.

Suwa et al. [37] observed that Acropora digitifera polyps reared for 10 days at low $\mathrm{pH}(\mathrm{pH} 7.3$ and 7.6) were significantly smaller than those reared at ambient conditions $(\mathrm{pH}$ 8.0 ), although it is unclear whether polyp "size" measured coral tissue and/or skeleton. Kurihara [46] reported "disturbed" and "malformed" Acropora tenuis polyps following settlement; however, methods and quantitative results were not provided for this study, and it is, therefore, difficult to interpret the results. Jokiel et al. [50] observed no difference in the size of Pocillopora damicornis settlers that recruited to acidified and control mesocosms over a 10-month period, indicating that some species may show higher levels of resistance to acidification.

Anlauf et al. [90] reported a temperature-dependent effect of acidification on calcification of Porites panamensis recruits. Acidification $(-0.2$ to $-0.25 \mathrm{pH}$ units) alone decreased calcification by only $3 \%$, but acidification combined with warming $\left(+1{ }^{\circ} \mathrm{C}\right)$ resulted in a $30 \%$ reduction in calcification rates. Interestingly, a $4^{\circ} \mathrm{C}$ warming (25$29^{\circ} \mathrm{C}$ ) had no effect on the response of F. fragum recruits to decreased $\Omega_{\text {arag }}$ [39]. An interaction between temperature and acidification has previously been shown to influence the growth response of adult corals [104] and is a critical area of research that deserves further attention.

Larval and juvenile calcification in some marine invertebrates may be more sensitive to acidification than adults, as has been shown for at least one bivalve and one echinoderm (reviewed in [46]). Maier et al. [105] showed that calcification in younger polyps of Lophelia pertusa was more sensitive to acidified seawater than older polyps. Waldbusser et al. [106] found a size dependent $\mathrm{pH}$ effect on calcification in juvenile hard clams (Mercenaria spp.), where smaller individuals were more heavily impacted than larger ones. For some marine invertebrates, the heightened sensitivity of early life history stages may, in part, be due to the presence of amorphous calcium carbonate (ACC) precursors that can occur at the onset of calcification and later stabilize into less soluble forms of $\mathrm{CaCO}_{3}$. ACC is 30 times more soluble than calcite $[107,108]$, rendering it particularly vulnerable to acidified conditions. Many marine invertebrates undergo ontological changes in mineral composition, from ACC to aragonite and sometimes calcite. Larval spines of urchins form via an ACC precursor that later stabilizes into calcite $[109,110]$; the oyster, Crassostrea virginica secretes aragonite in the larval stages and calcite in the adult stage [111]; similarly, shell formation in molluscan larvae involves an initial, transient ACC phase $[112,113]$, and it has been suggested that the same may be true for corals [114], but see [115].
Slowed postsettlement growth resulting from exposure to acidification may translate into increased juvenile mortality. Risk of coral mortality has been shown to be inversely proportional to juvenile growth rate and colony size [116118 ] with up to a $20 \%$ increase in survivorship associated with a $0.5 \mathrm{~mm}$ increase in diameter of 4 -month-old juveniles of certain species [118]. While postsettlement mortality was not reported for any of the above growth experiments, it is important to note that mortality rates observed in laboratory studies typically do no approximate survivorship of juveniles in situ. Under laboratory conditions, factors known to affect early survivorship on the reef (e.g., competition with algae and other benthic organisms, sedimentation effects, predation) are often controlled or eliminated to minimize influences on growth other than the desired treatment effect. Therefore, survivorship in the laboratory may overestimate survivorship on the reef.

In addition to potential increases in juvenile mortality, both the onset of sexual maturity $[119,120]$ and fecundity $[117,121,122]$ of reef-building corals are known to be a function of colony size. Therefore, depressed growth would likely result in longer time spent in juvenile (nonreproductive) life stages, which, in combination with adult loss, would shift population structures toward dominance by smaller size classes, ultimately reducing effective population sizes, population fecundity, and the resilience of reef-building corals [123].

\section{Algal Symbiosis}

Knowledge of the effects of ocean acidification on the establishment of coral-algal symbioses is based on relatively few studies. Suwa et al. [37] showed that acidification by 0.4 and $0.7 \mathrm{pH}$ units delayed the onset of symbiosis in Acropora digitifera primary polyps. This effect was temporary (2 days maximum), and all polyps contained algae within four days of infection. The ecological significance of such a delay in the onset of symbiosis is unknown. Anlauf et al. [90] found that temperature, but not $\mathrm{CO}_{2}$, significantly reduced the number of zooxanthellae in primary polyps of Porites panamensis following $42 \mathrm{~d}$ exposure to $\mathrm{pH}$ 7.8. Further studies are needed to assess if ocean acidification influences the establishment and functionality of the symbiotic relationship in newly settled corals.

\section{Survivorship}

While acidification may impose numerous sublethal effects on early stages of corals, most studies indicate that mortality does not directly result from exposure to acidified seawater [37, 69, 90]. Suwa et al. [37] found that while survival of Acropora tenuis larvae was significantly higher at $\mathrm{pH} 7.3$ than $\mathrm{pH} 7.6$, survival of $A$. digitifera larvae did not differ significantly among $\mathrm{pH}$ treatments. The lack of a consistent pattern led the authors to conclude that survivorship of coral larvae was not affected by acidified seawater. Nakamura et al. [69] found no effect of $\mathrm{CO}_{2}$-induced acidification $(\mathrm{pH}$ $7.3,7.6,8.0)$ on survivorship of Acropora digitifera larvae 
following 3 and 7 days of exposure. Anlauf et al. [90] observed near 100\% survival of Porites panamensis recruits reared at both $\mathrm{pH} 7.8$ and $\mathrm{pH} 8.0$ over the course of 42 days.

Acidification-induced mortality has been reported for other species of marine invertebrates. The most striking example was reported by Dupont et al. [40], where a $\mathrm{pH}$ reduction of 0.2 units induced $100 \%$ mortality of brittlestar (Ophiothrix fragilis) larvae within 8 days. Mortality following exposure to acidified seawater has also been reported for other echinoderms, including four urchin species-one tropical (Tripneustes gratilla), two temperate (Pseudechinus huttoni, Evechinus chloroticus), and one polar (Sterechinus neumayeri) [41]. Shirayama and Thornton [124] reported increased mortality in one of two studies for two species of urchins, Hemicentrotus pulcerrimus and Echinometra mathaei, and one gastropod Strombus luhuanus. Larval survivorship of several shellfish species also decreases with increasing acidity: Saccostrea glomerata [125], Crassostrea virginica, Mercenaria mercenaria, and Argopecten irradians [91, 92]. Mortality was reported for copepod nauplii (Acartia erythraea, [126]) exposed to OA scenarios, though significant differences were noted only when acidification was severe $\left(+5,000\right.$ and $\left.+10,000 \mathrm{ppm} \mathrm{CO}_{2}\right)$.

\section{Considerations for Future Experiments}

Because ocean acidification is a young and rapidly developing field of science, it is fitting to reflect on aspects of experimental design and methodology that may help guide future studies. Facets that have already been discussed, such as the use of multiple sperm concentrations in fertilization studies, are not revisited, but there are several other aspects of experimental design that deserve consideration. Interspecies and intertaxa comparisons are often complicated by variations in methodologies (e.g., acid addition versus $\mathrm{CO}_{2}$ gas bubbling to manipulate seawater carbonate chemistry). Some studies discussed here indicate little difference in biological response between acid-manipulated experiments and $\mathrm{CO}_{2}$ gas-manipulated experiments [39]. Nonetheless, efforts should be made to comply with the recently released Guides to Best Practices [127, 128] to allow for standardized methodologies that facilitate more meaningful comparisons between studies. Inclusion of power analyses for studies with no treatment effect would provide confidence that results are indicative of resistance to acidification, as opposed to a limitation in the experimental design.

While the suitability of techniques for manipulating seawater chemistry has received recent consideration [127], little attention has been given to the relevance of experimental conditions to the natural environment. Unlike open ocean waters, coral reefs experience large diurnal and seasonal fluctuations in carbonate chemistry that are primarily driven by biology (e.g., photosynthesis and respiration) [129]. Despite this, many experimental seawater systems employ constant treatment conditions that eliminate inherent variability. These systems generally target $p \mathrm{CO}_{2} / \mathrm{pH}$ values that are projected to occur in coming centuries. These projections are based on air-sea fluxes in the open ocean and their relevance to shallow-water ecosystems such as coral reefs is not well understood [129]. The scientific community has a poor understanding of the importance of background variability in determining an organism's response to an environmental stressor. While variability may not be a concern for ephemeral life history stages such as fertilization, attempts should be made to incorporate variability into long-term experiments (e.g., growth, survivorship) to both mimic the natural environment and cater to more realistic organism responses. This can be achieved through the use of experimental designs/systems that superimpose treatment levels on top of natural trends in temperature and $\mathrm{CO}_{2}$.

\section{Conclusion}

The studies reviewed here demonstrate that ocean acidification has the potential to affect sexual reproduction and multiple early life history stages of corals that are critical to reef persistence and resilience. While further studies are essential, available information indicates that affected processes may include sperm motility and fertilization success, larval metabolism, larval settlement, and postsettlement growth and calcification. These effects may occur via both direct (e.g., depressed sperm motility, fertilization, larval respiration, growth and calcification) and indirect (e.g., changes in substrate conditions that favor settlement) pathways. Implications of these effects include reduced larval supply, a major determinant of recruit density $[10,130]$, and depressed recruitment, which will likely compromise coral reef resilience, or the ability of reefs to recover from disturbance. Slowed growth may trigger numerous repercussions, including, but not limited to, elevated juvenile mortality and shifts in population size structure.

Sessile, broadcast-spawning organisms face several population bottlenecks during early life, including fertilization, settlement, and early postsettlement survivorship and growth [130]. As a result, natural larval and early juvenile mortality of many marine invertebrates often exceeds $99 \%$ $[131,132]$. For corals, research using artificial settlement substrates indicates that coral recruit survivorship during the first year is extremely low, generally reported to be as low as $0.2-6.0 \%$ survivorship, depending on the species and environment $[133,134]$. Stochastic events or chronic stressors that further reduce survivorship during these critical stages have the potential to significantly alter future population sizes $[130,131]$. Although ocean acidification is now recognized as a substantial threat to marine calcifiers and their ability to secrete calcium carbonate shells and/or skeletons, the studies reviewed here demonstrate that increasing $p \mathrm{CO}_{2}$ has the potential to impact multiple life history stages of corals, including critical processes independent of calcification.

Negative impacts on successive life history stages may cumulate in such a way that the overall effect on recruitment is severe. For example, results of studies conducted with the threatened Caribbean elkhorn coral, Acropora palmata, indicate that ocean acidification has the potential to reduce fertilization success by $12-13 \%$ (averaged across all sperm concentrations) and to decrease settlement success by $45-69 \%$ at $p \mathrm{CO}_{2}$ concentrations expected for the middle and end of 
this century. The compounding effect of ocean acidification on these early life history stages translates into a $52-73 \%$ reduction in the number of larval settlers on the reef. The net impact on recruitment will likely be even greater, given that depressed postsettlement growth may translate into elevated rates of postsettlement mortality [28]. Given the long generation time of corals, multigenerational studies are difficult, if not impossible; however, an attempt should be made to conduct studies evaluating multiple life history stages to allow for the evaluation of cumulative and/or carryover effects [135].

Future research should investigate the existence of genotypes and/or species that show resistance to $\mathrm{pH} / \mathrm{pCO}_{2}$ changes at multiple life history stages (e.g., fertilization, settlement, growth), as recruitment failure in these species may not be multiplicative. Within species that demonstrate sensitivity to ocean acidification, additional work needs to be done; there is a need to further investigate organisms' abilities to acclimatize and/or adapt to elevated $p \mathrm{CO}_{2}$ given prolonged exposure. Although early life history stages are posited to be the most sensitive, the most sensitive life history stage may differ amongst species [46], and variation in life history characteristics (e.g., brooders versus spawners) may prove some species more resilient than others [136]. Focusing efforts on the protection and cultivation of more adaptable species or genotypes may improve the effectiveness of coral preservation and restoration efforts.

\section{Acknowledgments}

The authors would like to thank B. Mason and four anonymous reviewers for constructive feedback that greatly improved this paper. Portions of this paper were supported through work conducted at the University of Miami, Rosenstiel School of Atmospheric Science.

\section{References}

[1] J. E. N. Veron, Corals in Space and Time, University of New South Wales Press, Sydney, Australia, 1995.

[2] H. Cesar, L. Burke, and L. Pet-Soede, The Economics of Worldwide Coral Reef Degradation, Cesar Environmental Economics Consulting, Arnhem, The Netherlands, 2003.

[3] O. Hoegh-Guldberg, "Climate change, coral bleaching and the future of the world's coral reefs," Marine and Freshwater Research, vol. 50, no. 8, pp. 839-866, 1999.

[4] T. A. Gardner, I. M. Côté, J. A. Gill, A. Grant, and A. R. Watkinson, "Long-term region-wide declines in Caribbean corals," Science, vol. 301, no. 5635, pp. 958-960, 2003.

[5] T. P. Hughes, A. H. Baird, D. R. Bellwood et al., "Climate change, human impacts, and the resilience of coral reefs," Science, vol. 301, no. 5635, pp. 929-933, 2003.

[6] K. E. Carpenter, M. Abrar, G. Aeby et al., "One-third of reef-building corals face elevated extinction risk from climate change and local impacts," Science, vol. 321, no. 5888, pp. 560-563, 2008.

[7] C. Wilkinson, Status of Coral Reefs of the World, Australian Institute of Marine Science, Townsville, Australia, 2008.
[8] C. M. Eakin, J. A. Morgan, S. F. Heron et al., "Caribbean corals in crisis: record thermal stress, bleaching, and mortality in 2005," PLoS ONE, vol. 5, no. 11, Article ID e13969, 2010.

[9] R. Richmond, "Reproduction and recruitment in corals: critical links in the persistence of reefs," in Life and Death of Coral Reefs, C. Birkeland, Ed., pp. 175-197, Chapman \& Hall, New York, NY, USA, 1997.

[10] T. P. Hughes and J. E. Tanner, "Recruitment failure, life histories, and long-term decline of Caribbean corals," Ecology, vol. 81, no. 8, pp. 2250-2263, 2000.

[11] R. Ritson-Williams, S. N. Arnold, N. D. Fogarty, R. S. Steneck, M. J. A. Vermeij, and V. J. Paul, "New perspectives on ecological mechanisms affecting coral recruitment on reefs," Smithsonian Contributions to the Marine Science, vol. 38, pp. 437-457, 2009.

[12] S. Gaines and J. Roughgarden, "Larval settlement rate-a leading determinant of structure in an ecological community of the marine intertidal zone," Proceedings of the National Academy of Sciences of the United States of America, vol. 82, pp. 3707-3711, 1985.

[13] P. Doherty and T. Fowler, "An empirical test of recruitment limitation in a coral reef fish," Science, vol. 263, no. 5149, pp. 935-939, 1994.

[14] P. L. Harrison and C. C. Wallace, "Reproduction, dispersal and recruitment of scleractinian corals," in Ecosystems of the World: Coral Reefs, Z. Dubinsky, Ed., vol. 25, pp. 133-207, Elsevier Press, Amsterdam, The Netherlands, 1990.

[15] B. Riegl, S. J. Purkis, J. Keck, and G. P. Rowlands, "Monitored and modeled coral population dynamics and the refuge concept," Marine Pollution Bulletin, vol. 58, no. 1, pp. 24-38, 2009.

[16] IPCC, Climate Change 2007: The Physical Science Basis: Contribution of Working Group I to the Fourth Assessment Report of the Intergovernmental Panel on Climate Change, Cambridge University Press, New York, NY, USA, 2007.

[17] U. Siegenthaler, T. F. Stocker, E. Monnin et al., "Atmospheric science: stable carbon cycle-climate relationship during the late pleistocene," Science, vol. 310, no. 5752, pp. 1313-1317, 2005.

[18] R. E. Zeebe, J. C. Zachos, and G. R. Dickens, "Carbon dioxide forcing alone insufficient to explain PalaeoceneEocene Thermal Maximum warming," Nature Geoscience, vol. 2, no. 8, pp. 576-580, 2009.

[19] C. L. Sabine, R. A. Feely, N. Gruber et al., "The oceanic sink for anthropogenic $\mathrm{CO}_{2}$," Science, vol. 305, no. 5682, pp. 367371, 2004.

[20] J. N. Havenhand, F. R. Buttler, M. C. Thorndyke, and J. E. Williamson, "Near-future levels of ocean acidification reduce fertilization success in a sea urchin," Current Biology, vol. 18, no. 15, pp. R651-R652, 2008.

[21] M. Morita, R. Suwa, A. Iguchi et al., "Ocean acidification reduces sperm flagellar motility in broadcast spawning reef invertebrates," Zygote, vol. 18, no. 2, pp. 103-107, 2010.

[22] H. Kurihara and Y. Shirayama, "Effects of increased atmospheric $\mathrm{CO}_{2}$ on sea urchin early development," Marine Ecology Progress Series, vol. 274, pp. 161-169, 2004.

[23] K. E. Reuter, K. E. Lotterhos, R. N. Crim, C. A. Thompson, and C. D. G. Harley, "Elevated $\mathrm{pCO}_{2}$ increases sperm limitation and risk of polyspermy in the red sea urchin Strongylocentrotus franciscanus," Global Change Biology, vol. 17, no. 1, pp. 163-171, 2011. 
[24] M. Byrne, N. Soars, P. Selvakumaraswamy, S. A. Dworjanyn, and A. R. Davis, "Sea urchin fertilization in a warm, acidified and high $\mathrm{pCO}_{2}$ ocean across a range of sperm densities," Marine Environmental Research, vol. 69, no. 4, pp. 234-239, 2010.

[25] L. M. Parker, P. M. Ross, and W. A. O'Connor, “The effect of ocean acidification and temperature on the fertilization and embryonic development of the Sydney rock oyster Saccostrea glomerata (Gould 1850)," Global Change Biology, vol. 15, no. 9, pp. 2123-2136, 2009.

[26] L. M. Parker, P. M. Ross, and W. A. O'Connor, “Comparing the effect of elevated $\mathrm{pCO}_{2}$ and temperature on the fertilization and early development of two species of oysters," Marine Biology, vol. 157, no. 11, pp. 2435-2452, 2010.

[27] J. N. Havenhand and P. Schlegel, "Near-future levels of ocean acidification do not affect sperm motility and fertilization kinetics in the oyster Crassostrea gigas," Biogeosciences, vol. 6, no. 12, pp. 3009-3015, 2009.

[28] R. Albright, B. Mason, M. Miller, and C. Langdon, "Ocean acidification compromises recruitment success of the threatened Caribbean coral Acropora palmata," Proceedings of the National Academy of Sciences of the United States of America, vol. 107, no. 47, pp. 20400-20404, 2010.

[29] K. E. Arnold, H. S. Findlay, J. I. Spicer, C. L. Daniels, and D. Boothroyd, "Effect of $\mathrm{CO}_{2}$-related acidification on aspects of the larval development of the European lobster, Homarus gammarus (L.)," Biogeosciences, vol. 6, no. 8, pp. 1747-1754, 2009.

[30] H. S. Findlay, M. A. Kendall, J. I. Spicer, and S. Widdicombe, "Future high $\mathrm{CO}_{2}$. in the intertidal may compromise adult barnacle semibalanus balanoides survival and embryonic development rate," Marine Ecology Progress Series, vol. 389, pp. 193-202, 2009.

[31] H. S. Findlay, M. A. Kendall, J. I. Spicer, and S. Widdicombe, "Post-larval development of two intertidal barnacles at elevated $\mathrm{CO}_{2}$ and temperature," Marine Biology, vol. 157, no. 4, pp. 725-735, 2010.

[32] M. R. McDonald, J. B. McClintock, C. D. Amsler et al., "Effects of ocean acidification over the life history of the barnacle Amphibalanus amphitrite," Marine Ecology Progress Series, vol. 385, pp. 179-187, 2009.

[33] H. Kurihara, S. Kato, and A. Ishimatsu, "Effects of increased seawater $\mathrm{pCO}_{2}$ on early development of the oyster Crassostrea gigas," Aquatic Biology, vol. 1, pp. 91-98, 2007.

[34] R. P. Ellis, J. Bersey, S. D. Rundle, J. M. Hall-Spencer, and J. I. Spicer, "Subtle but significant effects of $\mathrm{CO}_{2}$ acidified seawater on embryos of the intertidal snail, Littorina obtusata," Aquatic Biology, vol. 5, no. 1, pp. 41-48, 2009.

[35] R. Albright, B. Mason, and C. Langdon, "Effect of aragonite saturation state on settlement and post-settlement growth of Porites astreoides larvae," Coral Reefs, vol. 27, no. 3, pp. 485490, 2008.

[36] A. L. Cohen, D. C. McCorkle, S. De Putron, G. A. Gaetani, and K. A. Rose, "Morphological and compositional changes in the skeletons of new coral recruits reared in acidified seawater: insights into the biomineralization response to ocean acidification," Geochemistry, Geophysics, Geosystems, vol. 10, no. 7, Article ID Q07005, pp. 1-12, 2009.

[37] R. Suwa, M. Nakamura, M. Morita et al., "Effects of acidified seawater on early life stages of scleractinian corals (Genus Acropora)," Fisheries Science, vol. 76, no. 1, pp. 93-99, 2010.

[38] R. Albright and C. Langdon, "Ocean acidification impacts multiple early life history processes of the Caribbean coral
Porites astreoides," Global Change Biology, vol. 17, no. 7, pp. 2478-2487, 2011.

[39] S. J. de Putron, D. C. McCorkle, A. L. Cohen, and A. B. Dillon, "The impact of seawater saturation state and bicarbonate ion concentration on calcification by new recruits of two Atlantic corals," Coral Reefs, vol. 30, no. 2, pp. 321-328, 2011.

[40] S. Dupont, J. Havenhand, W. Thorndyke, L. Peck, and M. Thorndyke, "Near-future level of $\mathrm{CO}_{2}$-driven ocean acidification radically affects larval survival and development in the brittlestar Ophiothrix fragilis," Marine Ecology Progress Series, vol. 373, pp. 285-294, 2008.

[41] D. Clark, M. Lamare, and M. Barker, "Response of sea urchin pluteus larvae (Echinodermata: Echinoidea) to reduced seawater $\mathrm{pH}$ : a comparison among a tropical, temperate, and a polar species," Marine Biology, vol. 156, no. 6, pp. 11251137, 2009.

[42] H. Sheppard Brennand, N. Soars, S. A. Dworjanyn, A. R. Davis, and M. Byrne, "Impact of ocean warming and ocean acidification on larval development and calcification in the sea urchin Tripneustes gratilla," PloS One, vol. 5, no. 6, article e11372, 2010.

[43] M. J. O’Donnell, A. E. Todgham, M. A. Sewell et al., “Ocean acidification alters skeletogenesis and gene expression in larval sea urchins," Marine Ecology Progress Series, vol. 398, pp. 157-171, 2010.

[44] M. J. O’Donnell, L. M. Hammond, and G. E. Hofmann, "Predicted impact of ocean acidification on a marine invertebrate: elevated $\mathrm{CO}_{2}$ alters response to thermal stress in sea urchin larvae," Marine Biology, vol. 156, no. 3, pp. 439-446, 2009.

[45] A. E. Todgham and G. E. Hofmann, "Transcriptomic response of sea urchin larvae Strongylocentrotus purpuratus to $\mathrm{CO}_{2}$-driven seawater acidification," Journal of Experimental Biology, vol. 212, no. 16, pp. 2579-2594, 2009.

[46] H. Kurihara, "Effects of $\mathrm{CO}_{2}$-driven ocean acidification on the early developmental stages of invertebrates," Marine Ecology Progress Series, vol. 373, pp. 275-284, 2008.

[47] P. J. Edmunds, "Evidence for a decadal-scale decline in the growth rates of juvenile scleractinian corals," Marine Ecology Progress Series, vol. 341, pp. 1-13, 2007.

[48] R. C. Babcock, G. D. Bull, P. L. Harrison et al., "Synchronous spawnings of 105 scleractinian coral species on the Great Barrier Reef," Marine Biology, vol. 90, no. 3, pp. 379-394, 1986.

[49] B. Vargas-Ángel, S. B. Colley, S. M. Hoke, and J. D. Thomas, "The reproductive seasonality and gametogenic cycle of Acropora cervicornis off Broward County, Florida, USA," Coral Reefs, vol. 25, no. 1, pp. 110-122, 2006.

[50] P. L. Jokiel, K. S. Rodgers, I. B. Kuffner, A. J. Andersson, E. F. Cox, and F. T. Mackenzie, "Ocean acidification and calcifying reef organisms: a mesocosm investigation," Coral Reefs, vol. 27, no. 3, pp. 473-483, 2008.

[51] M. Fine and D. Tchernov, "Scleractinian coral species survive and recover from decalcification," Science, vol. 315, no. 5820, p. 1811, 2007.

[52] M. Holcomb, A. L. Cohen, and D. C. McCorkle, "Gender bias in the impact of ocean acidification on corals," in Proceedings of the Ocean Sciences Meeting, Portland, Ore, USA, 2010.

[53] A. L. Cohen and M. Holcomb, "Why corals care about ocean acidification: uncovering the mechanism," Oceanography, vol. 22, pp. 118-127, 2009.

[54] R. Albright, Effects of ocean acidification on early life history stages of Caribbean scleractinian corals, Ph.D. thesis, University of Miami/Rosenstiel School of Marine and Atmospheric Science, 2011. 
[55] M. Byrne, M. Ho, P. Selvakumaraswamy, H. D. Nguyen, S. A. Dworjanyn, and A. R. Davis, "Temperature, but not pH, compromises sea urchin fertilization and early development under near-future climate change scenarios," Proceedings of the Royal Society B, vol. 276, no. 1663, pp. 1883-1888, 2009.

[56] C. F. Hollows, E. L. Johnston, and D. J. Marshall, "Copper reduces fertilisation success and exacerbates Allee effects in the field," Marine Ecology Progress Series, vol. 333, pp. 51-60, 2007.

[57] P. A. Dinnel, J. M. Link, and Q. J. Stober, "Improved methodology for a sea urchin sperm cell bioassay for marine waters," Archives of Environmental Contamination and Toxicology, vol. 16, no. 1, pp. 23-32, 1987.

[58] J. Oliver and R. Babcock, "Aspects of the fertilization ecology of broadcast spawning corals: sperm dilution effects and in situ measurements of fertilization," Biological Bulletin, vol. 183, no. 3, pp. 409-417, 1992.

[59] M. Omori, H. Fukami, H. Kobinata, and M. Hatta, "Significant drop of fertilization of Acropora corals in 1999: an aftereffect of heavy coral bleaching?" Limnology and Oceanography, vol. 46, no. 3, pp. 704-706, 2001.

[60] D. J. Marshall, "Reliably estimating the effect of toxicants on fertilization success in marine broadcast spawners," Marine Pollution Bulletin, vol. 52, no. 7, pp. 734-738, 2006.

[61] M. Morita, A. Nishikawa, A. Nakajima et al., "Eggs regulate sperm flagellar motility initiation, chemotaxis and inhibition in the coral Acropora digitifera, A. gemmifera and A. tenuis," Journal of Experimental Biology, vol. 209, no. 22, pp. 4574 4579, 2006.

[62] R. Christen, R. W. Schackmann, and B. M. Shapiro, "Metabolism of sea urchin sperm. Interrelationships between intracellular $\mathrm{pH}$, ATPase activity, and mitochondrial respiration," Journal of Biological Chemistry, vol. 258, no. 9, pp. 5392-5399, 1983.

[63] J. C. Coll, B. F. Bowden, G. V. Meehan et al., "Chemical aspects of mass spawning in corals. 1.Sperm-attractant molecules in the eggs of the scleractinian coral Montipora digitata," Marine Biology, vol. 118, no. 2, pp. 177-182, 1994.

[64] A. Szmant-Froelich, P. Yevich, and M. Q. Q. Pilson, "Gametogenesis and early development of the temperate coral Astrangia danae (Anthozoa: Scleractinia)," Biological Bulletin, vol. 158, pp. 257-269, 1980.

[65] H. W. Smith and G. H. A. Clowes, "The influence of hydrogen ion concentration on the fertilization process in Arbacia, Asterias, and Chaetopterus eggs," Biological Bulletin, vol. 47, pp. 333-344, 1924.

[66] A. Tyler and J. Schultz, "Inhibition and reversal of fertilization in eggs of the echiuroid worm, Urechis caupo," Journal of Experimental Zoology, vol. 63, pp. 509-532, 1932.

[67] A. Lopo and V. D. Vacquier, "The rise and fall of intracellular p H of sea urchin eggs after fertilisation," Nature, vol. 269, no. 5629, pp. 590-592, 1977.

[68] J. D. Johnson, D. Epel, and M. Paul, "Intracellular pH and activation of sea urchin eggs after fertilisation," Nature, vol. 262, no. 5570, pp. 661-664, 1976.

[69] M. Nakamura, S. Ohki, A. Suzuki, and K. Sakai, "Coral larvae under ocean acidification: survival, metabolism, and metamorphosis," PLoS ONE, vol. 6, no. 1, article e14521, 2011.

[70] R. Metzger, F. J. Sartoris, M. Langenbuch, and H. O. Pörtner, "Influence of elevated $\mathrm{CO}_{2}$ concentrations on thermal tolerance of the edible crab Cancer pagurus," Journal of Thermal Biology, vol. 32, no. 3, pp. 144-151, 2007.
[71] R. Rosa and B. A. Seibel, "Synergistic effects of climaterelated variables suggest future physiological impairment in a top oceanic predator," Proceedings of the National Academy of Sciences of the United States of America, vol. 105, no. 52, pp. 20776-20780, 2008.

[72] H. O. Pörtner, A. Reipschläger, and N. Heisler, "Acid-base regulation, metabolism and energetics in Sipunculus nudus as a function of ambient carbon dioxide level," Journal of Experimental Biology, vol. 201, no. 1, pp. 43-55, 1998.

[73] B. Michaelidis, C. Ouzounis, A. Paleras, and H. O. Pörtner, "Effects of long-term moderate hypercapnia on acid-base balance and growth rate in marine mussels Mytilus galloprovincialis," Marine Ecology Progress Series, vol. 293, pp. 109-118, 2005.

[74] V. J. Fabry, B. A. Seibel, R. A. Feely, and J. C. Orr, "Impacts of ocean acidification on marine fauna and ecosystem processes," International Council for the Exploration of the Sea Journal of Marine Science, vol. 65, no. 3, pp. 414-432, 2008.

[75] E. Beniash, A. Ivanina, N. S. Lieb, I. Kurochkin, and I. M. Sokolova, "Elevated level of carbon dioxide affects metabolism and shell formation in oysters Crassostrea virginica," Marine Ecology Progress Series, vol. 419, pp. 95-108, 2010.

[76] S. C. Hand, "Metabolic dormancy in aquatic invertebrates," in Advances in Comparative and Environmental Physiology, R. Gilles, Ed., vol. 8, pp. 1-50, Springer, Heidelberg, Germany, 1991.

[77] M. Langenbuch, C. Bock, D. Leibfritz, and H. O. Pörtner, "Effects of environmental hypercapnia on animal physiology: a ${ }^{13} \mathrm{C}$ NMR study of protein synthesis rates in the marine invertebrate Sipunculus nudus," Comparative Biochemistry and Physiology, vol. 144, no. 4, pp. 479-484, 2006.

[78] M. Langenbuch and H. O. Pörtner, "High sensitivity to chronically elevated $\mathrm{CO}_{2}$ levels in a eurybathic marine sipunculid," Aquatic Toxicology, vol. 70, no. 1, pp. 55-61, 2004.

[79] N. Okubo, H. H. Yamamoto, F. Nakaya, and K. Okaji, "Oxygen consumption of a single embryo/planula in the reefbuilding coral Acropora intermedia," Marine Ecology Progress Series, vol. 366, pp. 305-309, 2008.

[80] C. N. Mundy and R. C. Babcock, "Role of light intensity and spectral quality in coral settlement: implications for depthdependent settlement?" Journal of Experimental Marine Biology and Ecology, vol. 223, no. 2, pp. 235-255, 1998.

[81] P. T. Raimondi and A. N. C. Morse, "The consequences of complex larval behavior in a coral," Ecology, vol. 81, no. 11, pp. 3193-3211, 2000.

[82] A. M. Szmant and M. G. Meadows, "Developmental changes in coral larval buoyancy and vertical swimming behavior: implications for dispersal and connectivity," in Proceedings of the 10th International Coral Reef Symposium, vol. 1, pp. 431437, 2006.

[83] D. E. Morse, N. Hooker, A. N. C. Morse, and R. A. Jensen, "Control of larval metamorphosis and recruitment in sympatric agariciid corals," Journal of Experimental Marine Biology and Ecology, vol. 116, no. 3, pp. 193-217, 1988.

[84] D. E. Morse, A. N. C. Morse, P. T. Raimondi, and N. Hooker, "Morphogen-based chemical flypaper for Agaricia humilis coral larvae," Biological Bulletin, vol. 186, no. 2, pp. 172-181, 1994.

[85] A. N. C. Morse, K. Iwao, M. Baba, K. Shimoike, T. Hayashibara, and M. Omori, "An ancient chemosensory mechanism brings new life to coral reefs," Biological Bulletin, vol. 191, no. 2, pp. 149-154, 1996. 
[86] A. J. Heyward and A. P. Negri, "Natural inducers for coral larval metamorphosis," Coral Reefs, vol. 18, no. 3, pp. 273279, 1999.

[87] N. S. Webster, L. D. Smith, A. J. Heyward et al., "Metamorphosis of a scleractinian coral in response to microbial biofilms," Applied and Environmental Microbiology, vol. 70, no. 2, pp. 1213-1221, 2004.

[88] C. L. Birrell, L. J. McCook, and B. L. Willis, "Effects of algal turfs and sediment on coral settlement," Marine Pollution Bulletin, vol. 51, no. 1-4, pp. 408-414, 2005.

[89] I. B. Kuffner, L. J. Walters, M. A. Becerro, V. J. Paul, R. RitsonWilliams, and K. S. Beach, "Inhibition of coral recruitment by macroalgae and cyanobacteria," Marine Ecology Progress Series, vol. 323, pp. 107-117, 2006.

[90] H. Anlauf, L. D'Croz, and A. O'Dea, “A corrosive concoction: the combined effects of ocean warming and acidification on the early growth of a stony coral are multiplicative," Journal of Experimental Marine Biology and Ecology, vol. 397, no. 1, pp. 13-20, 2011.

[91] S. C. Talmage and C. J. Gobler, "The effects of elevated carbon dioxide concentrations on the metamorphosis, size, and survival of larval hard clams (Mercenaria mercenaria), bay scallops (Argopecten irradians), and eastern oysters (Crassostrea virginica)," Limnology and Oceanography, vol. 54, no. 6, pp. 2072-2080, 2009.

[92] S. C. Talmage and C. J. Gobler, "Effects of past, present, and future ocean carbon dioxide concentrations on the growth and survival of larval shellfish," Proceedings of the National Academy of Sciences of the United States of America, vol. 107, no. 40, pp. 17246-17251, 2010.

[93] K. R. N. Anthony, D. I. Kline, G. Diaz-Pulido, S. Dove, and O. Hoegh-Guldberg, "Ocean acidification causes bleaching and productivity loss in coral reef builders," Proceedings of the National Academy of Sciences of the United States of America, vol. 105, no. 45, pp. 17442-17446, 2008.

[94] I. B. Kuffner, A. J. Andersson, P. L. Jokiel, K. S. Rodgers, and F. T. MacKenzie, "Decreased abundance of crustose coralline algae due to ocean acidification," Nature Geoscience, vol. 1, no. 2, pp. 114-117, 2008.

[95] C. R. Agegian and F. T. Mackenzie, "Calcareous organisms and sediment mineralogy on a mid-depth bank in the Hawaiian archipelago," Pacific Science, vol. 43, no. 1, pp. 5666, 1989.

[96] L. N. Plummer and F. T. Mackenzie, "Predicting mineral solubility from rate data: application to the dissolution of magnesium calcites," American Journal of Science, vol. 274, pp. 61-83, 1974.

[97] J. W. Morse, A. J. Andersson, and F. T. Mackenzie, "Initial responses of carbonate-rich shelf sediments to rising atmospheric $\mathrm{pCO}_{2}$ and "ocean acidification": role of high Mgcalcites," Geochimica et Cosmochimica Acta, vol. 70, no. 23, pp. 5814-5830, 2006.

[98] A. H. Baird and A. N. C. Morse, "Induction of metamorphosis in larvae of the brooding corals Acropora palifera and Stylophora pistillata," Marine and Freshwater Research, vol. 55, no. 5, pp. 469-472, 2004.

[99] Y. Golbuu and R. H. Richmond, "Substratum preferences in planula larvae of two species of scleractinian corals, Goniastrea retiformis and Stylaraea punctata," Marine Biology, vol. 152, no. 3, pp. 639-644, 2007.

[100] L. Harrington, K. Fabricius, G. De'Ath, and A. Negri, "Recognition and selection of settlement substrata determine post-settlement survival in corals," Ecology, vol. 85, no. 12, pp. 3428-3437, 2004.
[101] R. Ritson-Williams, V. J. Paul, S. N. Arnold, and R. S. Steneck, "Larval settlement preferences and post-settlement survival of the threatened Caribbean corals Acropora palmata and A. cervicornis," Coral Reefs, vol. 29, no. 1, pp. 71-81, 2010.

[102] C. Langdon and M. J. Atkinson, "Effect of elevated $\mathrm{pCO}_{2}$ on photosynthesis and calcification of corals and interactions with seasonal change in temperature/ irradiance and nutrient enrichment," Journal of Geophysical Research C, vol. 110, no. 9, Article ID C09S07, pp. 1-16, 2005.

[103] J. A. Kleypas and K. K. Yates, "Coral reefs and ocean acidification," Oceanography, vol. 22, no. 4, pp. 108-117, 2009.

[104] S. Reynaud, N. Leclercq, S. Romaine-Lioud, C. FerrierPagès, J. Jaubert, and J. P. Gattuso, "Interacting effects of $\mathrm{CO}_{2}$ partial pressure and temperature on photosynthesis and calcification in a scleractinian coral," Global Change Biology, vol. 9, no. 11, pp. 1660-1668, 2003.

[105] C. Maier, J. Hegeman, M. G. Weinbauer, and J. P. Gattuso, "Calcification of the cold-water coral lophelia pertusa under ambient and reduced pH," Biogeosciences, vol. 6, no. 8, pp. 1671-1680, 2009.

[106] G. G. Waldbusser, H. Bergschneider, and M. A. Green, "Sizedependent $\mathrm{pH}$ effect on calcification in post-larval hard clam Mercenaria spp," Marine Ecology Progress Series, vol. 417, pp. 171-182, 2010.

[107] L. Brečević and A. E. Nielsen, "Solubility of amorphous calcium carbonate," Journal of Crystal Growth, vol. 98, no. 3, pp. 504-510, 1989.

[108] Y. Politi, T. Arad, E. Klein, S. Weiner, and L. Addadi, "Sea urchin spine calcite forms via a transient amorphous calcium carbonate phase," Science, vol. 306, no. 5699, pp. 1161-1164, 2004.

[109] E. Beniash, J. Aizenberg, L. Addadi, and S. Weiner, "Amorphous calcium carbonate transforms into calcite during sea urchin larval spicule growth," Proceedings of the Royal Society $B$, vol. 264, no. 1380, pp. 461-465, 1997.

[110] Y. Politi, R. A. Metzler, M. Abrecht et al., "Transformation mechanism of amorphous calcium carbonate into calcite in the sea urchin larval spicule," Proceedings of the National Academy of Sciences of the United States of America, vol. 105, no. 45 , pp. 17362-17366, 2008.

[111] H. B. Stenzel, "Oysters: composition of the larval shell," Science, vol. 145, no. 3628, pp. 155-156, 1964.

[112] I. M. Weiss, N. Tuross, L. Addadi, and S. Weiner, "Mollusc larval shell formation: amorphous calcium carbonate is a precursor phase for aragonite," Journal of Experimental Zoology, vol. 293, no. 5, pp. 478-491, 2002.

[113] J. C. Marxen, W. Becker, D. Finke, B. Hasse, and M. Epple, "Early mineralization in Biomphalaria glabrata: microscopic and structural results," Journal of Molluscan Studies, vol. 69, no. 2, pp. 113-121, 2003.

[114] A. Meibom, J. P. Cuif, F. Hillion et al., "Distribution of magnesium in coral skeleton," Geophysical Research Letters, vol. 31, no. 23 ,article L23306, 4 pages, 2004.

[115] P. L. Clode, K. Lema, M. Saunders, and S. Weiner, "Skeletal mineralogy of newly settling Acropora millepora (Scleractinia) coral recruits," Coral Reefs, vol. 30, no. 1, pp. 1-8, 2010.

[116] T. P. Hughes and J. B. C. Jackson, "Population dynamics and life histories of foliaceous corals," Ecological Monographs, vol. 55, no. 2, pp. 142-166, 1985.

[117] R. C. Babcock, "Comparative demography of three species of scleractinian corals using age- and size-dependent classifications," Ecological Monographs, vol. 61, no. 3, pp. 225-244, 1991. 
[118] R. Babcock and C. Mundy, "Coral recruitment: consequences of settlement choice for early growth and survivorship in two scleractinians," Journal of Experimental Marine Biology and Ecology, vol. 206, no. 1-2, pp. 179-201, 1996.

[119] E. A. Chornesky and E. C. Peters, "Sexual reproduction and colony growth in the scleractinian coral Porites astreoides," Biological Bulletin, vol. 172, no. 2, pp. 161-177, 1987.

[120] A. M. Szmant, "Sexual reproduction by the Caribbean reef corals Montastrea annularis and M. cavernosa," Marine Ecology Progress Series, vol. 74, no. 1, pp. 13-25, 1991.

[121] M. P. McGuire, "Timing of larval release by Porites astreoides in the northern Florida Keys," Coral Reefs, vol. 17, no. 4, pp. 369-375, 1998.

[122] M. M. L. De Barros and D. O. Pires, "Aspects of the life history of Siderastrea stellata in the tropical Western Atlantic, Brazil," Invertebrate Reproduction and Development, vol. 49, no. 4, pp. 237-244, 2006.

[123] T. J. Done, "Coral community adaptability to environmental change at the scales of regions, reefs and reef zones," American Zoologist, vol. 39, no. 1, pp. 66-79, 1999.

[124] Y. Shirayama and H. Thornton, "Effect of increased atmospheric $\mathrm{CO}_{2}$ on shallow water marine benthos," Journal of Geophysical Research C, vol. 110, no. 9, Article ID C09S08, pp. 1-7, 2005.

[125] S. A. Watson, P. C. Southgate, P. A. Tyler, and L. S. Peck, "Early larval development of the sydney rock oyster saccostrea glomerata under near-future predictions of $\mathrm{CO}_{2}$ driven ocean acidification," Journal of Shellfish Research, vol. 28, no. 3, pp. 431-437, 2009.

[126] H. Kurihara, S. Shimode, and Y. Shirayama, "Effects of raised $\mathrm{CO}_{2}$ concentration on the egg production rate and early development of two marine copepods (Acartia steueri and Acartia erythraea)," Marine Pollution Bulletin, vol. 49, no. 910, pp. 721-727, 2004.

[127] U. Riebesell, V. J. Fabry, L. Hansson, and J.-P. Gattuso, Guide to Best Practices for Ocean Acidification Research and Data Reporting, Publications Office of the European Union, Luxembourgh, 2010.

[128] A. G. Dickson, C. L. Sabine, and J. R. Christian, Guide to Best Practices for Ocean $\mathrm{CO}_{2}$ Measurements, vol. 3, North Pacific Marine Science Organization, Sidney, British Columbia, Canda, 2007.

[129] K. R. N. Anthony, J. A. Kleypas, and J.-P. Gattuso, "Coral reefs modify their seawater carbon chemistry-implications for impacts of ocean acidification," Global Change Biology. In press.

[130] M. J. A. Vermeij and S. A. Sandin, "Density-dependent settlement and mortality structure the earliest life phases of a coral population," Ecology, vol. 89, no. 7, pp. 1994-2004, 2008.

[131] L. A. Gosselin and P. Y. Qian, "Juvenile mortality in benthic marine invertebrates," Marine Ecology Progress Series, vol. 146, no. 1-3, pp. 265-282, 1997.

[132] H. L. Hunt and R. E. Scheibling, "Role of early postsettlement mortality in recruitment of benthic marine invertebrates," Marine Ecology Progress Series, vol. 155, pp. 269301, 1997.

[133] S. J. L. Fairfull and V. J. Harriott, "Succession, space and coral recruitment in a subtropical fouling community," Marine and Freshwater Research, vol. 50, no. 3, pp. 235-242, 1999.

[134] J. Wilson and P. Harrison, "Post-settlement mortality and growth of newly settled reef corals in a subtropical environment," Coral Reefs, vol. 24, no. 3, pp. 418-421, 2005.
[135] J. A. Pechenik, "Larval experience and latent effectsMetamorphosis is not a new beginning," Integrative and Comparative Biology, vol. 46, no. 3, pp. 323-333, 2006.

[136] K. J. Kroeker, R. L. Kordas, R. N. Crim, and G. G. Singh, "Meta-analysis reveals negative yet variable effects of ocean acidification on marine organisms," Ecology Letters, vol. 13, no. 11, pp. 1419-1434, 2010. 

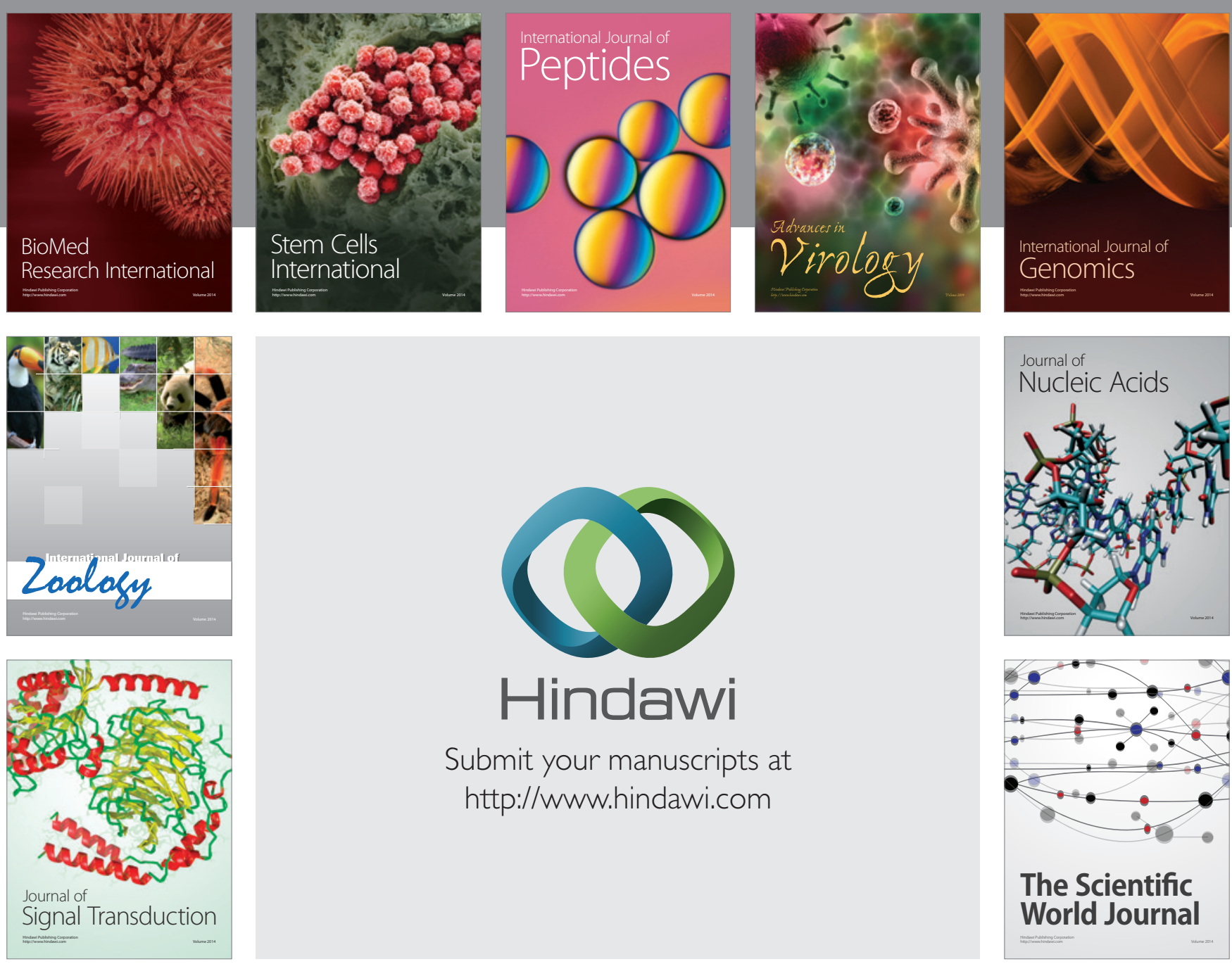

Submit your manuscripts at

http://www.hindawi.com
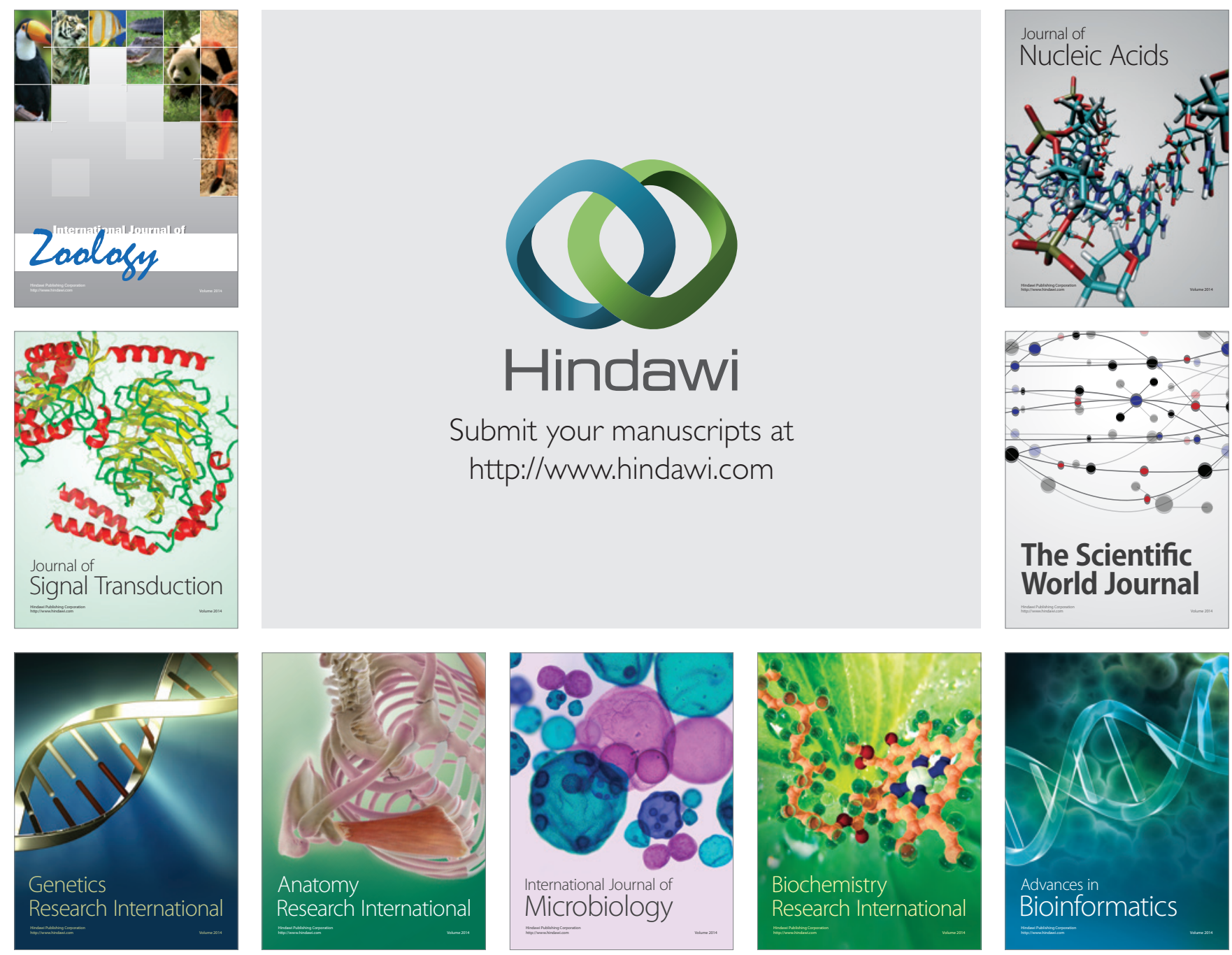

The Scientific World Journal
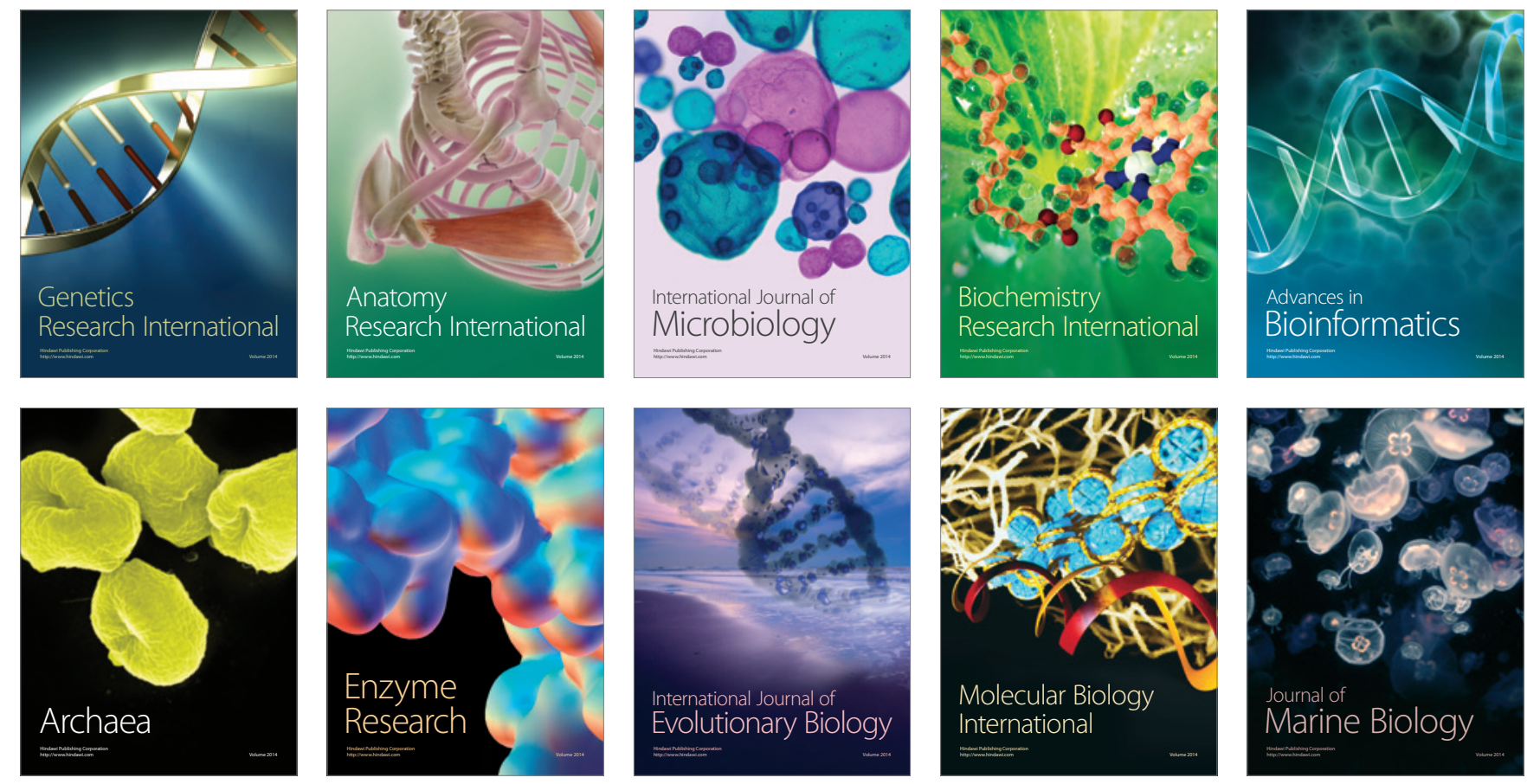